\title{
大容量キャパシタバンクの保護システム
}

$\begin{array}{llllll}\text { 正 員 } & \text { 佐 } & \text { 藤 } & \text { 康 宏 } & \text { (電総 研) } \\ \text { 正員 平 } & \text { 野 洋 一 } & \text { (電 総 研) } \\ \text { 正員山 } & \text { 口 } & \text { 作太郎 } & \text { (三菱電機) }\end{array}$

\section{Protective System for High Power Capacitor Bank}

Yasuhiro Sato, Member, Yoichi Hirano, Member (Electrotechnical Laboratory), Sataro Yamaguchi, Member (Mitsubishi Electric)

A new protection system for capacitor banks in case of short-circuiting accident is described.

A pulsed power system, which is composed of many capacitor units and closing switches, is well known for producing a controlled pulse current of high power as for the power source of plasma experimental device, etc.. According to the increase of a capacity of bank system, it becomes important to protect the whole bank system from the accident of short-circuiting in a capacitor unit.

Although some protective ideas have been proposed, these conventional ideas have not been sufficient means to absorb the energy flowing into the failure unit from other normal units. Constructing the new $1 \mathrm{MJ}$ capacitor bank for plasma experimental device, we designed a protective device of new conception. The new protection system, which is able to absorb the bank energy and to suppress the short-circuiting current flowing into the failure capacitor units, overcomes the defect in former protection systems. To confirm the utility of new protection system, we made a test of protection resistor imitating the actual bank circuit. Test result showed that absorvable energy for unit ceramic resistor amounted to $1500 \mathrm{joule} / \mathrm{cc}$. The new system is adopted to the bank system of TPE-1RM15 plasma experimental device.

キーワード: キャパシタバンク,パルスパワー, 保護システム, セラミック抵抗

\section{1.まえがき}

高電圧・大電流のパルスを発生する手段として,大 容量コンデンサを用いてエネルギーの蓄積を行い, 閉 路スイッチを始動することによって定められた時間に 瞬時に大電流を発生するキャパシタバンクは，エネル ギーの蓄積・移送手段が容易なことから, 数 $\mathrm{MJ}$ 程度 までのパルスパワー電源として利用される(1)。

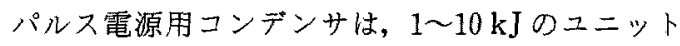
を必要な容量分だけ並列接続する構成を用いる。この 場合, キャパシタバンクの充電中などにユニット内の 構成素子や端子部などに邨て絶縁破壤事故が生じる と短絡状態になるので, 並列々接続された他の健全工 ニットのエネルギーが破壊ユニットに流れ込む。バン
クの全エネルギーが小さい場合㤝, 各キャパシタュニ ット間に接続された伝送用ケーブルなどの回路インピ ーダンス分によって短絡電流を㧕制し，エネルギーを 吸収することなどで事故の拡大を防ぐことが可能であ る。しかし装置の大型化などに伴いバンクエネルギー が大きくなると,ターブルによる保護だけでは不十分 になるので，故障スニットを外部で短絡したり，回路 から切り放してエネルギーが故障コニットに流入しな いように工夫された保護方式が提案されている。ただ し,これらは構造が複雑で必ずしも動作が確実でな

く、またエネルギーの吸収機構をもたないという不具 合をもつている。

当所の核融合実験装置においても，研究計画の進展 に伴ってキャパシタバンクの容量が大きくなってきた 
ため，事故時の安全対策をせまられることになった。 そこで従来方式の欠点を改善するものとして，エネル ギー吸収用抵抗を用いるとともに，キャパシタユニッ 卜を並列と直列の構成にした新しい保護方式を考案 $し^{(2) \sim(4)}$, 各種検討と基礎的実験を行った。その結果, 本システムの実用性が確認できたので，当所核融合実 蹥装置（TPE-1 RM 15）(5)の電源保護に応用した。

\section{2. キャパシタバンク保護システムの概要}

〈2・1〉従来の保護システム キャパシタバンク 破壤事故時の安全保護対策として, 故障ユニットに過 大なエネルギーが流入するのを防ぐための，種々の方 法が提案されている。図 1 は従来の安全装置の一例 $て^{(6)}$, 並列接続されたキャパシタュニット群 $C_{1} \sim C_{n}$ の中の 1 ユニット $\left(C_{x}\right)$ が短絡破壊事故を起こしたと き，他の健全ユニット群から $C_{x}$ へ流入する短絡電流 が発生する電磁力によって保護短絡器 $S_{x}$ の絶緑を破 壊して $C_{x}$ の高電压側を外部で短絡し, 故障ユニット に電流が流れ込まないようにして爆発などの事故の拡 大を防止するよう工夫したものである。

図 2 は保護短絡器の構造の一例を示している(7)。故

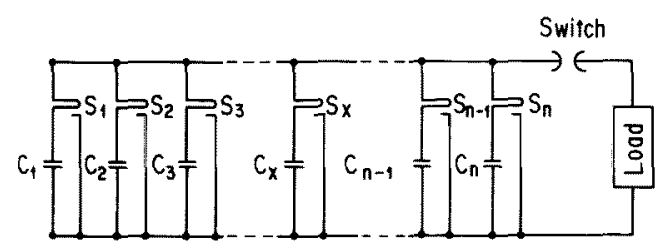

$C_{1} \sim C_{n}$ : capacitor units

$S_{1} \sim S_{n}$ : protective short-circuiting devices

図1従来のキャパシタバンク保護方式の一例

Fig. 1. Circuit diagram of a capacitor bank with a conventional protective means.

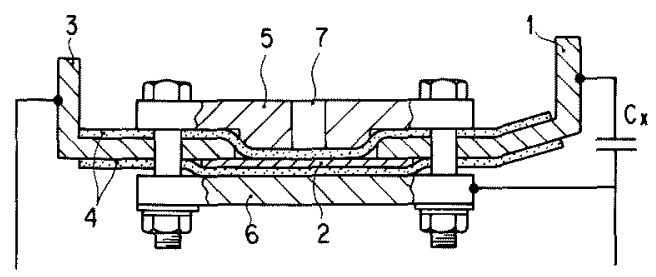

1,3 : terminal plates 2 : fuse element

4 : insulating sheet 5,6 : holder plates

7 : vent hole

$C_{x}$ : electrically falled capacitor unit

図 2 保護短絡器の構造の一例

Fig. 2. Sectional view of a protective short-circuiting device.
障ユニット $C_{x}$ へ流入する短絡電流が，ヒューズエレ メント 2 を爆発溶断させることによって端子間絶縁シ 一ト 4 を破壊短絡し，エネルギーが $C_{x}$ へ流入しない ように工夫したものである。

しかし，これらの方法では短絡器の動作が遅れると エネルギーが故障ユニットに流入し続けることにな り，事故の拡大をまねきかねない。また蓄積エネルギ 一を積極的に吸収する機能を備えていないので，短絡 器が動作した後も故障ユニットおよび放電回路自身の 抵抗分によってエネルギーが消費されるまで，大きな 短絡電流が回路を流れ続けるという欠点がある。

他の保護システムとして, 短絡電流を用いてヒュー ズを遮断し，故障ユニットを回路から切り放す方式が 提案されている(8)。しかしながら，電流の遮断時間が 速くなるほど正常動作時には発生しない大きな過渡電 圧が回路に誘起される。また，電流の遮断技術は閉路 技術に比べて格段に難しく安定な動作が保証されにく い。更に，ヒューズが動作しアークが消弧されるまで の間，過大な電流が故障ユニットを流れるので事故の 状沿を更に悪化させる恐机がある。

短絡器やヒューズを用いる方式は, 正常時の回路電 流では動作せず事故時の短絡電流で速やかに動作する ように調整する必要がある。また保護システムが動作 した場合，短絡器やヒューズを交換する必要があるな ど経済性を考慮すると, 従来提案されている短絡方式 およびヒューズ方式にはまだ改善すべき点が多い。

〈2・2〉 本システムの概要 上記問題点を解決す るものとして，キャパシタユニットの各々にエネルギ 一吸収用抵抗を挿入するとともに，キャパシタバンク のユニットを並列接続と直列接続の組合せにした図 3 に示す回路方式を提案した(2)(3)。

簡単のため, 最初に図 4 (a)のように同一容量 $C_{u}$ をもつキャパシタユニットが $n$ 個並列接続され，各 ユニットには抵抗值 $R_{a b}$ をつエネルギー吸収用抵 抗が挿入されている場合を考える。ここで， $x$ 番目の ユニット $C_{x}$ が短絡破壊事故を起こしたとすると，こ のときの等価回路は図 $4(\mathrm{~b})$ になる。キャパシタユニ ットの充電電圧, 内部抵抗を各々 $V_{c}, R_{c}$ とすると, 短絡電流 $I_{S H}$ 捛よび $C_{x}$ の乗入抵抗 $R_{x}$ (抵抗值 $=R_{a b}$ ) で吸収されるエネルギー $W_{x}$ は次式で表すことができ る。

$$
\begin{gathered}
I_{S H} \sim \frac{V_{c} \times(n-1)}{\left(R_{a b}+R_{c}\right) \times n} \cdots \ldots \ldots . . . \\
W_{x} \sim \frac{C_{u} V_{c}^{2} \times R_{a b} \times(n-1)^{2}}{2 \times\left(R_{a b}+R_{c}\right) \times n}
\end{gathered}
$$

$R_{a b}>R_{c}$ て，なおかつ並列数 $n$ が大きい場合は 


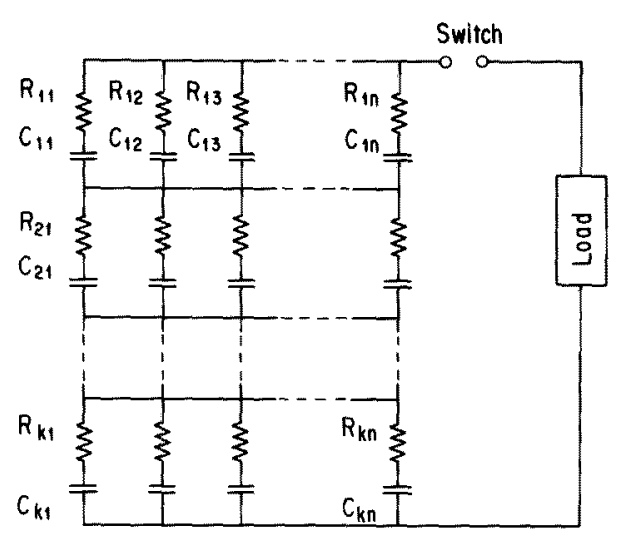

$C_{i j}$ : copacitor units

$R_{i j}$ : energy absorbing resistors

図 3 エネルギ一吸収用抵抗を用いたバンク 保濩システム（ニニット構成が $n$ 並列 $\times k$ 直列の場合)

Fig. 3. Improved circuit diagram with protective resistors (units are consist of $n^{-}$ parallel and $k$-series connection).

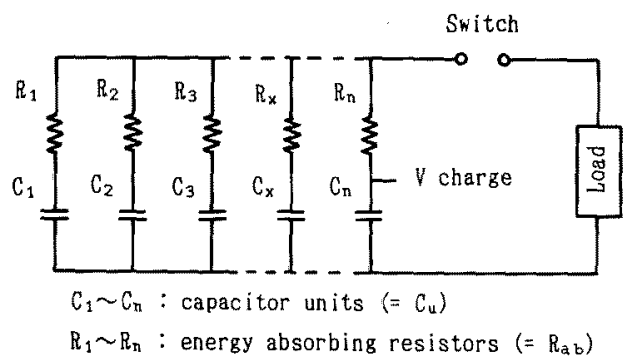

(a) 回路構成

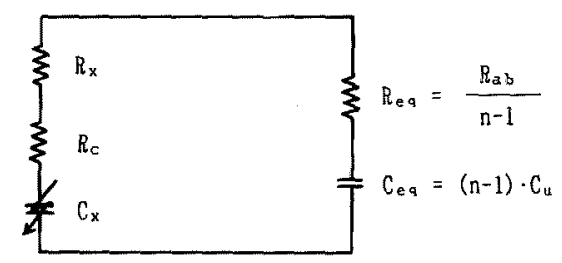

（b） C が短絡したときの等価回路

困 4 抵抗を用いたバンク保護ジステムの 簡単な構成例（ニニットが $n$ 並列の場合）

Fig. 4. Improved circuit diagram with protective resistors (units are connected in parallel).

$$
\begin{aligned}
& I_{S H} \sim V_{c} / R_{a b} \\
& W_{x} \sim n C_{u} V_{c}^{2} / 2
\end{aligned}
$$

となる。蓄積エネルギーの大部分が乗入抵抗 $R_{x}$ で吸

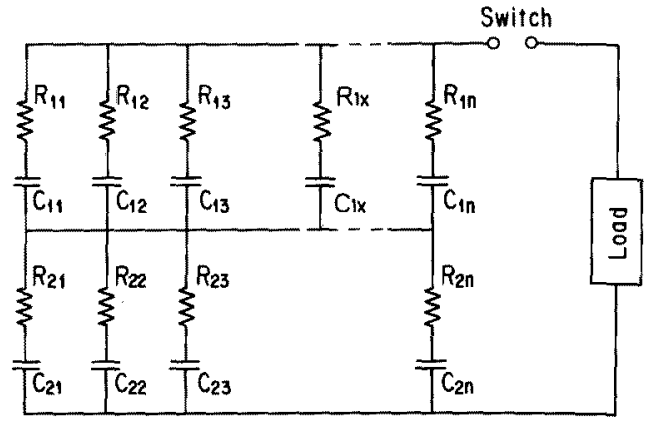

図 5 抵抗を用いたバンク保護システムの一例 (ユニットが $n$ 並列 $\times 2$ 直列の場合)

Fig. 5. Improved circuit diagram with protective resistors ( $n$-parallel and 2 -series connection).

収されることになり，故障ユニット内での吸収エネル ギー量は小さい。從って, 前節で述べた保護短絡器な どを用いなくても事故の規模が大きくなる心配はな い。また絶縁破壊時の短絡電流活捚入抵抗値によって 制限され，瞬時にしろ過大な電流が流れることはな い。更に，従来の保濩システムのように動作条件の調 整を行う煩わしさもなく，回路構成も単純である。挿 入抵抗により短絡時の寄生的な振動電流が防止される 効果も期待でき, 電源を構成する他の機器類への故障 時の悪影響を小さくすることが可能である。また保護 動作が働いた場合でも，基本的には抵抗などの構成素 子を交換する必要がないため経済的である。

次に図 5 のように，キャパシタュニットおよび保萑 抵抗が並列に接続され，これが 2 段に直列接続された 回路において，例えば 1 段目のユニット $C_{1 x}$ が故障 した場合を考える。図 4 の場合と同様に，並列接続さ れたユニット群のエネルギーの大部分が故障ユニット 部 $\left(C_{1 x}\right.$ および $\left.R_{1 x}\right)$ に流入するが，2段目のユニッ 卜群 $\left(C_{21} \sim C_{2 n}\right)$ は故障ユニットに对して短絡状態に はならないので，事故による影響の範围は 1 段目のみ に限定され， $R_{1 x}$ で吸収すべきエネルギー注全エネル ギーの $1 / 2$ でよいことになる。また，キャパシタユニ ットの充電電圧がバンク電圧の $1 / 2$ になるので, 抵抗 の耐電圧特性も皇になる。

同様の考方方で，図 3 のように，n個並列接続され たユニット群を直列に $k$ 段接続すると，短絡事故時 に事故の影響を受ける範囲は全バンクの $1 / k$ に限定 され，故障ユニットの插入抵抗が吸収すべきエネルギ 一量も同じく $1 / k$ になる。バンクの蓄積エネルギー や充電電圧などのバンクパラメー夕に応じてキャパシ タユニットの直並列構成を適当に選べば，插入抵抗の 
仕様を現実的なものとすることができる。

なお本システムは，正常放電時に放電エネルギーの 一部が㨂入抵抗部で損失を受けエネルギ一利用効率が 低下するという基本的な欠点をもつが，等価的な㨉入 抵抗值蜼 $R_{a b} / n$ となるので，バンク容量，すなわち キャパシタユニットの並列数 $n$ が大きくなるほどそ の損失分は小さくなる。ちなみに，本システムの導入 を検討した TPE-1 RM 装置の場合，保護抵抗を挿入 したことによる電流の低下分は約 $4.4 \%$ になるとの評 価が得られたが，安全性を考虑した場合に許容できる 損失と判断した。目標とする許容損失を同程度以下と した場合，1MJを超える一般的なバンクシステムに おいて本保護システムは十分に適応可能と考える。

\section{3. エネルギー吸収用抵抗について}

〈3・1〉抵抗の選定 抵抗を用いた保護方式が実 用化されるためには，パルス的なエネルギーに対して 必要な耐電圧, 耐電流拉よびエネルギー吸収能力を有 する抵抗を用いる必要がある。そこで，これらの目的 にかなうと思われる抵抗を選択し，その抵抗が上記保

表 1 セラミックディスク抵抗の特性 ${ }^{(9)}$ Table 1. Characteristics of ceramic resistor.

\begin{tabular}{|c|c|c|}
\hline 项 & 特 & 值 \\
\hline カサ比重 & 2.65 & \\
\hline 比熱 & $0.12 \sim 0.18$ & $\mathrm{cal} / \mathrm{g}^{\circ} \mathrm{C}$ \\
\hline 熱伝導率 & 0.003 & $\mathrm{cal} / \mathrm{cm} \cdot \mathrm{s}^{\circ} \mathrm{C}$ \\
\hline 温度係数 & $-0.05--0.1$ & $\% /{ }^{\circ} \mathrm{C}$ \\
\hline 熱膨張保数 & $4.0 \sim 7.0 \times 10^{-6}$ & $\mathrm{~cm} /{ }^{\circ} \mathrm{C}$ \\
\hline 最高使用温度 & 250 & ${ }^{\circ} \mathrm{C}$ \\
\hline 許容注入エネルギー & 300 & $\mathrm{~J} / \mathrm{cc}$ \\
\hline 接触圧力 & 4.0 & $\mathrm{~kg} / \mathrm{cm}^{2}$ \\
\hline
\end{tabular}
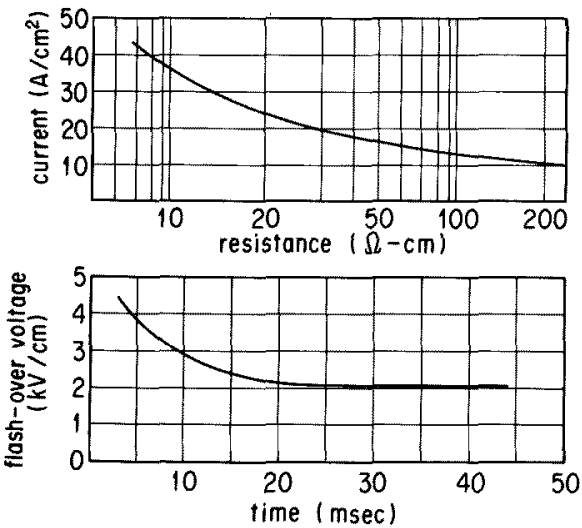

図 6 セラミックディスク抵抗の仕様(9)

Fig. 6. Characteristics of ceramic resistor.
護システムに利用できることを確認するため，またパ ルスパワーに対する抵抗の仕様および性質を明らかに するために，抵抗へのパルス印加試験を行った。

抵抗材料には金属系, 炭素系, セラミック系などが ある。それぞれに特徵をもつが，パルス的なエネルギ 一吸収用材料としてこれらを比較すると，アルミナセ ラミックに抵抗体を混ぜて焼結したセラミック系抵抗 が無誘導性であること, $500^{\circ} \mathrm{C}$ 程度までの温度領域で 安定した性能が得られること, 許容吸収エネルギーが 大きいことなどから，これを使用することとした。抵 抗形状には棒状，管状，ディスク状などがあるが，抵 抗招よびインダクタンスが最も小さくなり，許容吸収 エネルギーが大きい（ディスク抵抗では $300 \mathrm{~J} / \mathrm{cc}$, 棒 状抵抗では 70〜90 J/cc ${ }^{(9)}$ ) ディスク形状を採用した。 試験に用いた抵抗仕様を表 1 に示す。

〈3・2〉抵抗の性能確認試験 パルス印加試験に 用いる回路を図 7 に示す。 $80 \mathrm{~kJ}(10 \mathrm{kV})$ のキャパシ タバンクおよび可変インダクタによって実際の放電条 件を模擬したパルス電流を発生し，抵抗に印加される 電流，電圧，上昇温度を測定した。電流の測定には, ロゴスキーコイル，抢よび積分補正と感度補正のため にホール効果素子（商品名：LEMモジュール, LA 1500-S $\left.{ }^{(10)}\right)$ を併用した。電圧測定には岩崎通信 機製高電圧プローブ(HV-P 30 (11)) を，温度測定には 携帯型ディジタル放射温度計（チノー製 IR-AH ${ }^{(12)}$ ) を用いた。

抵抗は，抵抗值の異なるもの，形状の異なるもの， 抵抗表面の絶縁塗料の異なるものなど, 表 2 に示す 4 タイプについてそれぞれ数枚ずつ用意した。抵抗の電 流接触面は $4 \mathrm{~kg} / \mathrm{cm}^{2}$ 以上の指定圧力になるように導 電端子を加放るアルミニウム板 $(2 \mathrm{~cm}$ 厚 $)$ で挟んで 固定した ${ }^{(9)}$ 。

試験は，抵抗に印加される電圧，電流㧍よび表面温

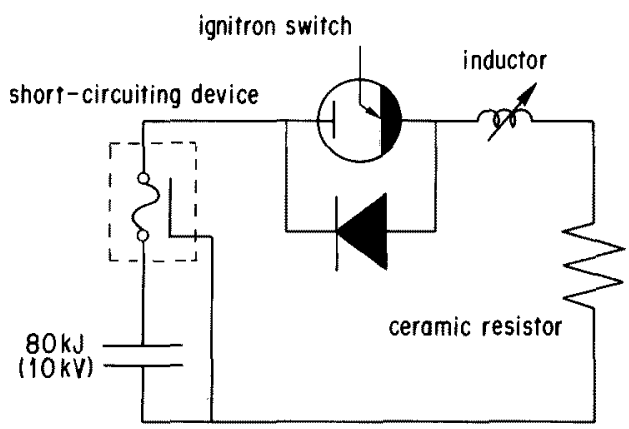

図 7 パルス印加試験用回路構成

Fig. 7. Test circuit. 
表 2 試験に用いた抵抗の夕イプ別パラメー夕

Table 2. Parameter of ceramic disk resistors.

\begin{tabular}{|c|c|c|c|c|c|}
\hline & \multicolumn{2}{|c|}{ 抵 } & \multicolumn{2}{|c|}{ 法 } & \multirow{2}{*}{$\begin{array}{l}\text { 沿面の } \\
\text { 䋓縁涂料 }\end{array}$} \\
\hline & 抵抗值 & 外半径 & 内半经 & 㖵 & \\
\hline タイプー1 & $0.25 \Omega$ & $37.5 \mathrm{~mm}$ & $15 \mathrm{~mm}$ & $25 \mathrm{~mm}$ & 有機望料 \\
\hline タイプ-2 & 0.56 & 37.5 & & 25 & 有機整料 \\
\hline タイプ-3 & 1.4 & 37.5 & 15 & 25 & 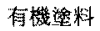 \\
\hline タイプー4 & 18 & 20 & & 25 & 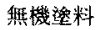 \\
\hline
\end{tabular}

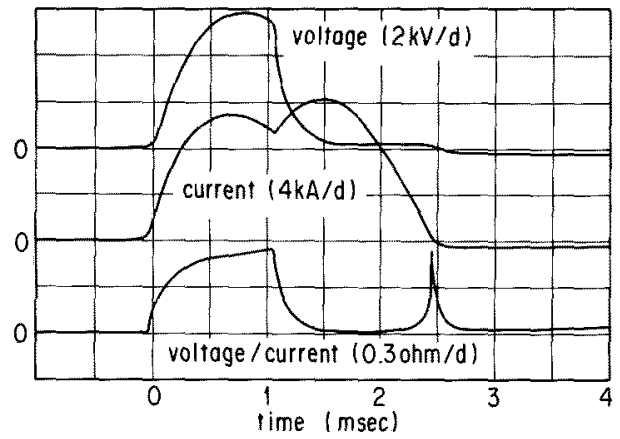

図 8 パルス印加試験時の電圧, 電流波形 (1.2 ms 秒後に絶縁破壊を生じた例)

Fig. 8. Measured voltage, current and resistance (beak down has occured at $t=$ $1.2 \mathrm{~ms})$.

度を同時測定しながら，抵抗が絶縁破壤されるまでエ ネルギーを徐々に上げていうた。図 8 は夕イプ20抵 抗への印加試験に扔いて，抵抗が $1.2 \mathrm{~ms}$ 後に絶縁破 壊したときの電圧，電流の測定例を示す。

〈3・3〉抵抗の吸収エネルギー量の算定 抵抗が 吸收するエネルギー量は，抵抗值 $(R)$ および抵抗に 印加される電在 $(V)$ ，電流 $(I)$ を同時測定することに よって以下の 4 通りの方法で計算できる。

（i）蓄積エネルギーを回路の抵抗比に分配する

(ii） $I^{2} \times R$ を時間積分する

（iii） $V \times I$ を時間積分する

(iv) $V^{2} / R$ を時間積分する

ここで，電流值や温度の変化などによって抵抗値が 変化することを考慮して，吸収エネルギーの計算には 抵抗值を用いないケース(iii)を採用することにした。 ただし，抵抗值が大きい場合（タイプ4）では電流值 の測定精度が悪くなるためケース(iv)を用いた。

以上の方法に基づく抵抗への吸収エネルギー量を， 表 3 にまとめた。表仙上れば，もっとも良かったのは タイプ $4(R=18 \Omega)$ の場合で， $1,500 \mathrm{~J} / \mathrm{cc}$ 程度まで エネルギーが吸収できており，パルスエネルギーに関 しては公表值の5倍程度まで使用できることがわかっ た。

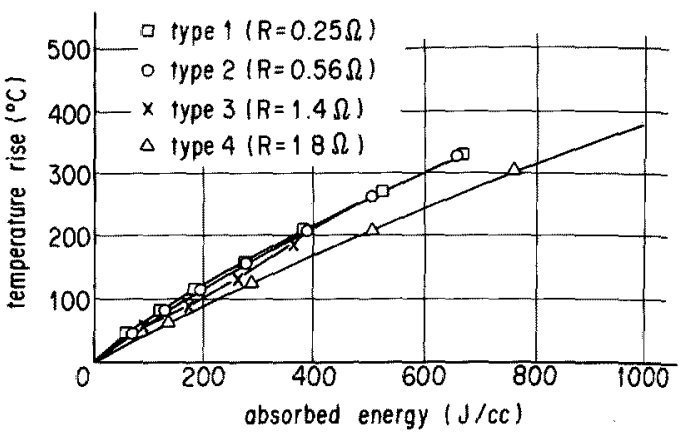

図 9 抵抗の吸収エネルギーと温度上昇值

Fig. 9. Absorbed energy vs. temperature rise.

〈3.4〉抵抗の温度測定最高使用温度は $250^{\circ} \mathrm{C}$ と指定されているが，パルスエネルギーによる温度上 昇の評価に対する知見がないため，パルス的な使用条 件下での抵抗温度を測定してその特性を明らかにする とともに，パルス加熱に対する熱歪などの問題点の有 無を検討することとした。温度測定には放射温度 計(12)を用いたが，抵抗表面の放射率の違いによる誤 差を避けるため，サーミス夕温度計を用いて校正を行 つた。その結果，放射温度計の放射率 $(\varepsilon)$ を 1 に設 定した場合にもっとも両温度計の指示が一致した。

以下, $\varepsilon=1$ 亿固定して放電試験時の抵抗温度の変 化を放射温度計で測定した。放電持続時間は $2 \sim 5 \mathrm{~ms}$

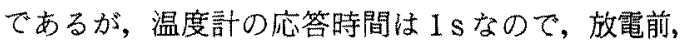

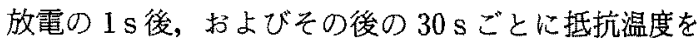
溳定して減衰時定数 $(\alpha)$ を求め, 以下の式加ら放電直 後のピーク温度 $\left(T_{\max }\right)$ を推算した。

$$
T-T_{0}=T_{\max } \exp (-\alpha t)
$$

ただし， $T_{0}$ : 放電前の抵抗温度, $t:$ 放電後 の経過時間, $T: t$ 秒後の温度

温度評価の結果を表 3 抢よび図 9 にまとめた。表 3 によると，抵抗体の最大温度上昇値は抵抗側面の絶縁 塗料によって異なっており，無機系塗料の場合に $500 \sim 600^{\circ} \mathrm{C}$, 有機系塗料の場合には $200 \sim 300^{\circ} \mathrm{C}$ であ った。これは後述のように，塗料の耐温度特性が異な っており，焼入れ処理時の温度以上では，塗料の蒸発 を生じ沿面耐電压を低下させるためである。図9よ り，注入エネルギーが大きくなると比例関係から若干 ずれてくるものの，温度上昇值は注济吸収エネルギー 量に比例している。このずれは，抵抗体およびアルミ ニウム支持体からの熱放射のバランスが高温で変わる ためであろう。同図より，抵抗の比熱 $C$ は 
表 3 テス卜結果

Table 3. Test result.

(a) 夕イプ1(抵抗值 $=0.25 \Omega$, 有機䒺染料)

\begin{tabular}{|c|c|c|c|c|c|}
\hline 番号 & $\begin{array}{c}\text { 充電麗压 } \\
(\mathrm{kV})\end{array}$ & $\begin{array}{l}\text { 吸収エネル } \\
\text { ギー }(\mathrm{J} / \mathrm{cc})\end{array}$ & $\begin{array}{c}\text { 䏜収パワー } \\
(\mathrm{kW} / \mathrm{cc})\end{array}$ & $\begin{array}{c}\text { 温度上珰 } \\
\left({ }^{\circ} \mathrm{C}\right)\end{array}$ & $\not \subset$ \\
\hline 1 & $\begin{array}{l}1.32 \\
2.38 \\
3.45 \\
4.51 \\
5.58 \\
6.65 \\
7.70 \\
8.76 \\
\end{array}$ & $\begin{array}{r}15 \\
40 \\
77 \\
135 \\
208 \\
298 \\
413\end{array}$ & $\begin{array}{r}23 \\
58 \\
108 \\
182 \\
282 \\
398 \\
546\end{array}$ & $\begin{array}{r}7 \\
22 \\
45 \\
74 \\
116 \\
158 \\
216\end{array}$ & $\begin{array}{l}\text { 沿面フラッシ } \\
\text { オーバ }\end{array}$ \\
\hline 2 & $\begin{array}{l}3.45 \\
4.51 \\
5.58 \\
6.65 \\
7.70 \\
8.76 \\
9.81 \\
\end{array}$ & $\begin{array}{l}144 \\
211 \\
309 \\
426 \\
561\end{array}$ & $\begin{array}{l}135 \\
195 \\
280 \\
380 \\
491 \\
628 \\
\end{array}$ & $\begin{array}{r}49 \\
82 \\
117 \\
163 \\
217 \\
282\end{array}$ & $\begin{array}{l}\text { 沿面フラッシ } \\
\text { オーパ }\end{array}$ \\
\hline 3 & $\begin{array}{l}3.45 \\
4.51 \\
5.58 \\
6.65 \\
7.70 \\
8.76\end{array}$ & $\begin{array}{r}74 \\
198 \\
298 \\
413 \\
539\end{array}$ & $\begin{array}{r}71 \\
\\
181 \\
269 \\
364 \\
467\end{array}$ & $\begin{array}{r}48 \\
77 \\
111 \\
163 \\
225 \\
285\end{array}$ & 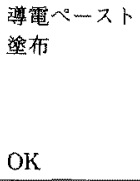 \\
\hline 4 & $\begin{array}{l}3.45 \\
4.51 \\
5.58 \\
6.65 \\
7.70 \\
8.76 \\
9.81\end{array}$ & $\begin{array}{r}68 \\
121 \\
190 \\
281 \\
391 \\
518 \\
672\end{array}$ & $\begin{array}{r}64 \\
112 \\
172 \\
252 \\
348 \\
450 \\
585\end{array}$ & $\begin{array}{r}45 \\
77 \\
114 \\
157 \\
210 \\
262 \\
326\end{array}$ & OK \\
\hline 5 & $\begin{array}{l}3.45 \\
4.51 \\
5.58 \\
6.65 \\
7.70 \\
8.76 \\
9.81\end{array}$ & $\begin{array}{r}77 \\
130 \\
201 \\
298 \\
418 \\
546 \\
699\end{array}$ & $\begin{array}{r}75 \\
122 \\
184 \\
271 \\
371 \\
481 \\
601\end{array}$ & $\begin{array}{r}41 \\
68 \\
105 \\
135 \\
193 \\
241 \\
296\end{array}$ & クラック \\
\hline
\end{tabular}

(c) タイプ 3 (抵抗檤 $=1.4 \Omega$, 有機采塗料)

\begin{tabular}{|c|c|c|c|c|c|}
\hline 番号 & $\begin{array}{c}\text { 充電霓压 } \\
(\mathrm{kV})\end{array}$ & $\begin{array}{l}\text { 吸収エホル } \\
\text { ギー(J/cc) }\end{array}$ & $\begin{array}{l}\text { 吸収パワー } \\
(\mathrm{kW} / \mathrm{cc})\end{array}$ & $\begin{array}{c}\text { 温度上氞 } \\
\text { (c) }\end{array}$ & $\not z$ \\
\hline 1 & $\begin{array}{l}3.45 \\
4.51 \\
5.58 \\
6.65 \\
7.70\end{array}$ & $\begin{array}{r}87 \\
174 \\
260 \\
361 \\
412\end{array}$ & $\begin{array}{r}62 \\
111 \\
164 \\
231 \\
944\end{array}$ & $\begin{array}{r}54 \\
85 \\
128 \\
182\end{array}$ & $\begin{array}{l}\text { 治面フラッシ } \\
\text { オーバ }\end{array}$ \\
\hline 2 & $\begin{array}{l}2.38 \\
3.45 \\
4.51 \\
5.58 \\
6.65\end{array}$ & $\begin{array}{r}41 \\
85 \\
179 \\
270 \\
284\end{array}$ & $\begin{array}{r}33 \\
67 \\
122 \\
183 \\
810\end{array}$ & $\begin{array}{r}24 \\
49 \\
83 \\
116\end{array}$ & 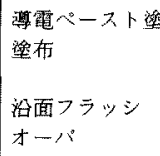 \\
\hline 3 & $\begin{array}{l}2.38 \\
3.45 \\
4.51 \\
5.58 \\
6.65\end{array}$ & $\begin{array}{r}79 \\
132 \\
228\end{array}$ & $\begin{array}{r}60 \\
102 \\
163\end{array}$ & $\begin{array}{r}25 \\
51 \\
84 \\
130\end{array}$ & 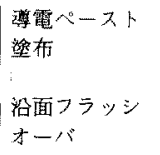 \\
\hline 4 & $\begin{array}{l}3.45 \\
4.51 \\
5.58 \\
6.65 \\
7.70\end{array}$ & $\begin{array}{r}83 \\
176 \\
265 \\
347 \\
431\end{array}$ & $\begin{array}{r}60 \\
110 \\
165 \\
228 \\
1,011\end{array}$ & $\begin{array}{r}56 \\
90 \\
133 \\
193\end{array}$ & アーク発生 \\
\hline
\end{tabular}

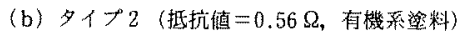

\begin{tabular}{|c|c|c|c|c|c|}
\hline 番号 & $\begin{array}{c}\text { 充雷電在 } \\
(\mathrm{kV})\end{array}$ & $\begin{array}{l}\text { 吸双工亦ル } \\
キ ゙ ー(\mathrm{~J} / \mathrm{cc})\end{array}$ & $\begin{array}{c}\text { 吸收,゚ワ- } \\
(\mathrm{kW} / \mathrm{cc})\end{array}$ & $\begin{array}{c}\text { 温度上昇 } \\
\left({ }^{\circ} \mathrm{C}\right)\end{array}$ & $\not \quad z$ \\
\hline 1 & $\begin{array}{l}4.51 \\
5.58 \\
6.65 \\
7.70 \\
8.76 \\
9.81\end{array}$ & $\begin{array}{l}116 \\
177 \\
262 \\
364 \\
475 \\
611\end{array}$ & $\begin{array}{l}113 \\
173 \\
249 \\
343 \\
538 \\
704\end{array}$ & $\begin{array}{r}66 \\
99 \\
139 \\
188 \\
239 \\
296\end{array}$ & OK \\
\hline 2 & $\begin{array}{r}3.45 \\
4.51 \\
5.58 \\
6.65 \\
7.70 \\
8.76 \\
9.81 \\
10.36\end{array}$ & $\begin{array}{r}71 \\
125 \\
194 \\
278 \\
386 \\
503 \\
657 \\
627\end{array}$ & $\begin{array}{r}71 \\
122 \\
188 \\
265 \\
362 \\
468 \\
600 \\
702\end{array}$ & $\begin{array}{r}42 \\
73 \\
108 \\
152 \\
204 \\
261 \\
322\end{array}$ & $\begin{array}{l}\text { 治面フラッシ } \\
\text { オーバ }\end{array}$ \\
\hline 3 & $\begin{array}{l}3.45 \\
4.51 \\
5.58 \\
6.65 \\
7.70 \\
8.76 \\
9.81\end{array}$ & $\begin{array}{r}75 \\
125 \\
196 \\
285 \\
390 \\
511 \\
370 \\
\end{array}$ & $\begin{array}{r}74 \\
122 \\
190 \\
273 \\
369 \\
480 \\
969 \\
\end{array}$ & $\begin{array}{r}41 \\
67 \\
99 \\
143 \\
188 \\
240\end{array}$ & $\begin{array}{l}\text { 浻面フラッシ } \\
\text { オーバ }\end{array}$ \\
\hline 4 & $\begin{array}{l}3.45 \\
4.51 \\
5.58 \\
6.65 \\
7.70 \\
8.76 \\
9.81\end{array}$ & $\begin{array}{r}76 \\
124 \\
186 \\
279 \\
393 \\
519\end{array}$ & $\begin{array}{r}66 \\
120 \\
181 \\
264 \\
371 \\
483\end{array}$ & $\begin{array}{r}65 \\
105 \\
153 \\
217 \\
282 \\
359\end{array}$ & OK \\
\hline 5 & $\begin{array}{l}2.38 \\
3.45 \\
4.51 \\
5.58 \\
6.65 \\
7.70 \\
8.76 \\
9.81\end{array}$ & $\begin{array}{r}39 \\
74 \\
131 \\
191 \\
280 \\
404 \\
519 \\
545\end{array}$ & $\begin{array}{r}39 \\
75 \\
126 \\
186 \\
270 \\
380 \\
484 \\
689\end{array}$ & $\begin{array}{r}38 \\
62 \\
96 \\
136 \\
185 \\
232\end{array}$ & $\begin{array}{l}\text { 沿面フラッシ } \\
\text { オーバ }\end{array}$ \\
\hline
\end{tabular}

(d) タイプ 4 (抵抗倠 $=18 \Omega$, 無機系塗料)

\begin{tabular}{|c|c|c|c|c|c|}
\hline 番号 & 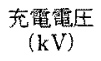 & \begin{tabular}{l} 
吸收工京儿 \\
\multirow{f}{*}{$-(\mathrm{J} / \mathrm{cc})$}
\end{tabular} & $\begin{array}{c}\text { 吸彼 }(\mathrm{kW} / \mathrm{cc}) \\
\end{array}$ & $\begin{array}{c}\text { 温度上暴 } \\
\left({ }^{\circ} \mathrm{C}\right)\end{array}$ & $\not \mp$ \\
\hline 1 & $\begin{array}{l}2.38 \\
3.45 \\
4.51 \\
5.58 \\
6.65 \\
7.70\end{array}$ & $\begin{array}{r}124 \\
\\
510 \\
796 \\
1,115 \\
1,458\end{array}$ & $\begin{array}{r}11 \\
39 \\
61 \\
86 \\
107\end{array}$ & $\begin{array}{r}65 \\
133 \\
224 \\
314 \\
428\end{array}$ & 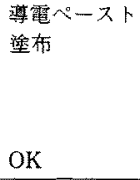 \\
\hline 2 & $\begin{array}{l}2.38 \\
3.45 \\
4.51 \\
5.58 \\
6.65 \\
7.70 \\
8.76 \\
9.81\end{array}$ & $\begin{array}{r}136 \\
288 \\
505 \\
760 \\
1,108 \\
1,480\end{array}$ & $\begin{array}{r}11 \\
22 \\
39 \\
60 \\
85 \\
116\end{array}$ & $\begin{array}{r}61 \\
128 \\
212 \\
307 \\
434 \\
537 \\
635\end{array}$ & $\begin{array}{l}\text { 導電ペースト } \\
\text { 鹉布 }\end{array}$ \\
\hline 3 & $\begin{array}{l}2.38 \\
3.45 \\
4.51 \\
5.58 \\
6.65 \\
8.76 \\
9.81\end{array}$ & $\begin{array}{r}146 \\
310 \\
542 \\
826 \\
1,202 \\
1,503\end{array}$ & $\begin{array}{r}11 \\
23 \\
40 \\
62 \\
87 \\
117\end{array}$ & $\begin{array}{r}71 \\
137 \\
230 \\
325 \\
467 \\
561\end{array}$ & $\begin{array}{l}\text { 導電ペースト } \\
\text { 塗布 }\end{array}$ \\
\hline
\end{tabular}


$C=0.17 \sim 0.21 \mathrm{cal} / \mathrm{g}^{\circ} \mathrm{C}$

と評価される。

\section{4. 試験結果のまとめ}

〈4・1〉抵抗形状の影響について 放電試験にお いて絶緑破壇を生じたときの放電痕を見ると，タイプ 2 および 4 の抵抗の場合注外部帰鲚電流路のあるほう の側面に集中しており，回路インピーダンスを最小に するように電流が流れていた。ドーナツ型タイプの抵 抗（タイプ 1，3）の場合は, 必ず抵抗の内側穴の工 ッジ部分から沿面絶縁破壊を生じていた。また,ドー ナツ型抵抗のほうが耐電圧が低い傾向にあった。これ は抵抗に絶緑塗料を塗布する際，外側沿面は吹付けで 行っているが，内側沿面は刷毛塗りであるため塗料が 不均一になっているのが原因の一つと思われる。また 端部での電界集中を抑えるため抵抗の角を丸めている が，作業性の違いから内側沿面部の仕上りが外側ほど 良くないことも影響しているのであろう。なお内側沿 面部に絶縁破壤を生じたとき，架間部の空気が瞬間的 に膨張して抵抗が破壊される場合があった。従って， 穴のないタイプの抵抗を用いるほうが適当であると判 断した。

〈4・2〉抵抗側面の塗料の影響抵抗の絶縁破壞 は必ず沿面フラッシオーバによっており，抵抗内部の 貫通による破壞はなかった。このため抵抗側面に絶緑 強化のための鉒料が鉒布されるが，緑色のものと白色 のものの 2 種類が用意されている。緑色の抵抗山有機 溶剂系の塗料で $350^{\circ} \mathrm{C}$ で焼入れ処理がされている。

一方，白色の抵抗はセラミック系塗料が用いられてお り $500^{\circ} \mathrm{C} て ゙$ 焼さ入れを行っている(13)。

そこで塗料の違いによる影響をテストしたところ， セラミック系塗料を用いた抵抗のほうが沿面耐電圧が 高く吸収エネルギーが大きかった。有機系鉒料の場合 は抵抗温度が $300^{\circ} \mathrm{C}$ 程度でフラッシオーバ事故を生 じているが, 無機系筮料の場合は $400^{\circ} \mathrm{C}$ を超えても 絶縁破壊を生じていない。これは, 有機系湮料のほう が低い抵抗温度で塗料成分の一部が抵抗側面から蒸発 し，この蒸発成分に沿ってフラッシオーバが生じたた めと思われる。絶縁破壊を生じた抵抗の表面状態を観 察したところ, 有機系塗料の場合は黒化していたが, 無機系塗料の場合は放電痕跡も目立たず外観の変化は 少なかった。

〈4・3〉抵抗接触面の処理万法による影響抵抗 の電流接触面を固定する集電端子にアルミニウムを用 いたが，大気中ではアルミニウム表面が酸化されて絶 縁膜ができるため接触抵抗が増加する。この対策とし
て, 当所のプラズマ実験装置TPE-2(14)では,アルミ ニウム導体の電流接触部に導電ペースト (15)を望布し て，表面の酸化を防ぐとともに電流接触の改善を図る ことにより，良好な結果を得た。

今回もアルミニウム表面の電流接触部に同様の導電 ペースト処理を施して，処理をしない場合との比較実 験を行ったが，試験結果からは明らかな違いは見られ なかった。ただし，抵抗温度が上昇して $200^{\circ} \mathrm{C}$ を超 えるとペースト塗布部から白煙が立つようになり，更 に $1 \sim 2 \mathrm{kV}$ 電圧を上げたところで絶緑破壤を生じた。 これは, 抵抗が加熱されることによってペースト中の 成分が蒸発し，これに沿ってアークが成長したためで あると考えられる。従って，試験結果に差異がないなら ば、ペース卜を用いないほうがよい。ただし，酸化膜 が形成されるほどの期間を㭁いて実験を行えば，異な る結果を生じた可能性がある。この弊害を避けるため には，銅板など絶縁性の酸化膜を作らない材料を用い るか, 蒸発成分の少ない導電ぺーストを使用する必要 があろう。

〈4・4〉抵抗の破壊原因について 抵抗へのパル ス印加試験の結果をみると, 抵抗のタイプ, 使用条件 などによって破壊限界が異なっているものの，最適条 件下ではパルス的な許容吸収エネルギーは $1,500 \mathrm{~J} / \mathrm{cc}$ 程度であることが明らかになった。そして，この限界 値を制限する要因に 3 種類あることが観察された。以 下に，その要因の内容および対策を列記する。

（1）抵抗の耐電圧限界を超えた場合抵抗汇印 加される電圧が許容值を超えたために生じる電圧的破 壊である。図8に例示したケースがこれにあたり，ほ ほ電圧のピーク ( $5.8 \mathrm{kV})$ で絶縁破壊を生じてい る。破壊はすべて沿面で生じ，蕡通破壇はなかった。 抵抗中心に穴のあいていない形状，無機系塗料を用い た抵抗，導電性ペーストを用いない方法を考慮するこ となどによって，大気中では $7 \mathrm{kV}(2.8 \mathrm{kV} / \mathrm{cm})$ の耐 纴が得られた。

（2）電流接触面てのアーキングによる破壊 抵抗と金属板との電流接続は点接触であるが, 電流 値が大きくなると接触部の許容值を超えて接触抵抗に よる局部的な過熱とアーキングを発生する。そして, 金属を溶融蒸発させてこれに沿って抵抗の絶緑破壊を 生じる。許容電流值を増やすには，接触抵抗を隇らす 何らかの対策を施す必要があるが，導電ぺーストを用 いて接触抵抗を減らす方法注必ずしも良い結果ではな かった。絶縁性酸化皮膜を作らない銅金属を用いるな どの対策を考えるべきである。

（3）抵抗温度上昇が原因となる破壊抵抗への 
吸収エネルギーにより抵抗が加熱され, 温度上昇が生 じる。抵抗が加熱されると, 抵抗中の揮発性成分が蒸 発してこれに沿ってアークが伸展し, 絶縁を破壊す る。また温度上昇はパルス的なので, 蒸発物の急激な 膨張や熱歪による亀裂などの影響を受けやすい。対策 としては, 温度上昇に耐える抵抗を用いること, 冷却 を考慮することなどである。ただし，無機系塗料を用 いた抵抗は許容温度上昇值が高いので, 他の破壊原因 によって制限される場合が多い。

\section{5. 本安全方式の TPE-1 RM 15 装置への応用}

プラズマ実験装置 TPE-1 RM 15 $5^{(16)}$ の OH 電源は Fast バンク（プラズマ電流立上げ用）と Flatバンク (電流維持用) の 2 系統から構成され[図 10（a ）]，そ れぞれ $624 \mathrm{~kJ}(10 \mathrm{kV} \times 2$ 直列, $6.5 \mathrm{~kJ}$ ユニット 96 台 で構成) および $400 \mathrm{~kJ}(3.3 \mathrm{kV} ， 3.7 \mathrm{~kJ}$ ユニット 108 台で構成) の電源容量をもつ。Fastバンク用始動ス イッチはイグナイトロンと金属接触スイッチが並列接 続で使用され ${ }^{(17)}$, Flat バンク用制御素子にはダイオ ードが用いられている。Fastバンクには負荷電流の

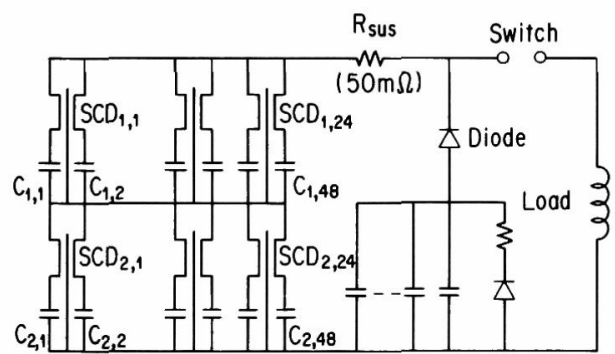

Fast Bank

Flat Bank

(a) 改造前の回路構成

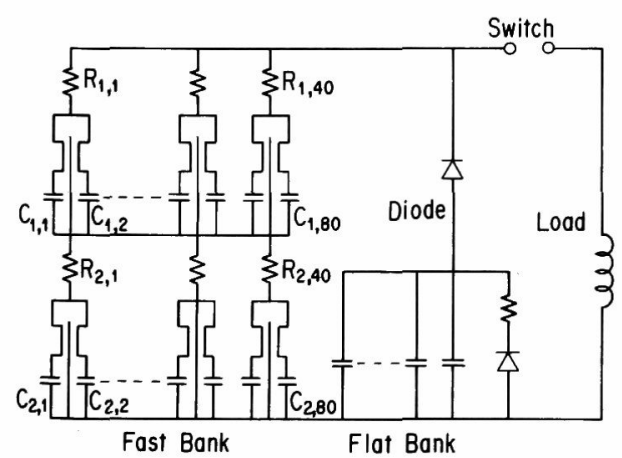

（b）バンク増設および保護回路改良後の回路構成

図 10 TPE-1 RM 15 装置の $\mathrm{OH}$ 電源

Fig. 10. Ohmic heating circuit of TPE-1 RM 15.
振動防止用に SUS 製抵抗 $R_{\text {sus }}(50 \mathrm{~m} \Omega)$ が挿入されて いる。キャパシタユニットの短絡破壊などに対するバ ンク保護用としては, 図 2 に示す方式(7)を用いた保護 短絡器と，ユニット間およびユニットからスイッチま での $5 \mathrm{~m}$ の同軸ケーブルのインピーダンス分による 短絡電流の抑制効果を期待していた。保護短絡器 (SCD) はキャパシタュニット 2 台に 1 個ずつ装着さ れている。上記 SUS 抵抗は Fast バンクに一括して 捙入されているため, ユニットの短絡事故に対する保 護とはなり得ていない。

研究の進展に伴い, Fast バンクを $1.04 \mathrm{MJ}(6.5 \mathrm{~kJ}$ ユニット 80 並列 $\times 2$ 直列) に増設することになった が，従来の対策だけではバンクの短絡破壊事故などが 生じた場合に $500 \mathrm{~kJ}$ 近いエネルギーが故障ユニット および短絡器に流れ込むとともに，伝送系の通電定格 を大幅に超えることが予想された。そこで，抵抗保護 による本安全システムを採用することとした。SUS 抵抗を撤去して，代わりにセラミックディスク抵抗 $\left(R_{1.1} \sim R_{2.40}\right)$ を各ュニットに分散配置した〔図 $10(\mathrm{~b})$ )。ここで, 回路パラメー夕によって決まる臨 界振動条件を満足する全抵抗值が $30 \mathrm{~m} \Omega$ となるので, これをキャパシタユニットに挿入される各抵抗（ $R_{1.1}$ $\sim R_{2.40}$ ) で分担すると, $0.6 \Omega$ と計算される。このと きの短絡電流は $(3)$ 式より与えられ, $15.8 \mathrm{kA}$ とな る。ちなみに，本抵抗がない場合の短絡電流は〜 400 $\mathrm{kA}$ と計算される。ユニットの短絡破壊事故時に各抵 抗が吸収すべきエネルギーは〜 $500 \mathrm{~kJ}$ である。一方, 各保護抵抗に前記予備実験で用いたタイプ 4 （無機系 塗料）のディスク抵抗を用いるとすると，抵抗 1 個当 たりの吸収エネルギーおよび耐電圧は, 試験結果より $1,500 \mathrm{~J} / \mathrm{cc}$ および $2.8 \mathrm{kV} / \mathrm{cm}$ となり, 温度上昇值は $500^{\circ} \mathrm{C}$ 程度になっている。抵抗素子 1 個当たりの体積 は $110.5 \mathrm{~cm}^{2}$ なので $165 \mathrm{~kJ}$ のエネル゙ーを吸収でき

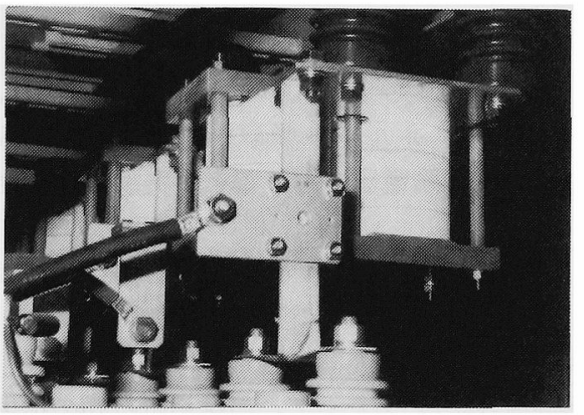

図 11 TPE-1 RM 15 用 OH 電源上の保護 抵抗器および短絡器

Fig. 11. One of protective devices on $\mathrm{OH}$ bank for TPE-1 RM 15. 
ることになる。従って抵抗は 4 個以上であればよい。 一方，保護動作時に抵抗部に印加されるサージ電圧を 模擬回路を使って測定したところ，充電電圧の 1.1 倍 が発生することがわかったので, 抵抗の必要な直列数 は 2 になる。ここで2 倍の安全率を見込むこととし， 抵抗素子を 4 直列 $\times 2$ 並列の構成にした。図 11 に保 護装置の実際の装着状態を示す。装着後 10,000 回を 超える放電試験を行っているが，保護回路が動作する ような事故はまだ起こっていない。

\section{6. まと め}

大容量キャパシタバンクの短絡事故時などに対する 安全保護対策として, 従来の保護短絡器やヒューズを 用いたシステムはバンクエネルギーを積極的に吸収処 理する機能をもっていなかったため, バンク容量が大 きくなるにつれて，事故の規模が拡大するなどの欠点 をもっていた。

そこで，従来の保護システムがもつ欠点を補うもの として, 短絡事故時にバンクの蓄積エネルギーを抵抗 に吸収させて事故の拡大を防ぐとともに，キャパシ夕 ユニットを並列と直列接続の組合せを用いて事故の及 ぽす範囲を限定するように工夫した新しい保護システ ムを提案した。そして，本システムの実用性に関する 確認試験を行った結果, その実用性が確認された。主 な特徵を以下に示す。

（1）保護短絡器やヒューズを用いる従来の方法と 比較して, 構成が単純で保護動作が確実である。

（2）保護動作後も基本的には部品の交換を必要と せず，メンテナンスフリーである。

（3）本方式は正常動作時の出力波形にはほとんど 影響を与えることなく, 事故時の短絡電流を安全值以 内に抑え，放出エネルギーを速やかに吸収してユニッ 卜爆発などの二次的事故の発生を確実に抑えることが できる。

（4）パルスエネルギー吸収用として, 無機系塗料 を用いたセラミック系焼結抵抗を用い机ば， 1.5 $\mathrm{kJ} / \mathrm{cc}$ 以上のエネルギー吸収能力, 気中で $2.8 \mathrm{kV} /$ $\mathrm{cm}$ 以上の沿面耐電圧をもつことが実験により確かめ られた。

以上の検討結果に基づいて，当所のプラズマ実験装 置 TPE-1 RM 15 の OH 電源を增設する際に, 本保 護システムを採用した。

本研究の遂行にあたって, 試験用抵抗類の提供をい ただくなど，東海高熱(株)殿には御協力をいただき深 く感謝いたします。電総研プラズマ研究室および三菱 電機核エネルギー開発部の関係者には，本研究を行う
機会を与えていただき，また各種の助力をいただいた ことを感謝します。

(平成 4 年 9 月 21 日受付，同 5 年 3 月 8 日再受付)

\section{文献}

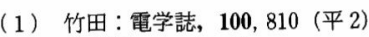

(2) 特願平 1-245491 号

(3) 特願平 1-245492 号

(4) 米国特許第 5087999 号

(5) T. Shimada, Y. Hirano, Y. Yagi, et al. : 14th Symp. on Fusion Technology, 1, p. 665 (1986)

(6) 特許第 738536 号

(7) 特開昭 57-88825 号

(8) MAXWELL カタロダ「Franklin High Voltage Fuses」

（9）東海高熱力タログ「エレマ抵抗器」，CC-30/1 OB (S61.07)

(10) LEM モジュールカタログ「LEM Module LA 1500-S」

(11) 取扱説明書「電圧プローブ HV - P 30」, G981-925101(K) (岩崎通信機)

(12) 「携带形デジタル故射温度計 IR - AH series」, チノー カタロク゚ Cat-NO. CP-35-07

（13）東海高熱(株)功らの情報による

（14）電総研魚報, 50, 5 (昭 63)

（15）新井 修：日立評論，48, No. 9, 1043 (昭 63)

（16）島田・平野・八木・小川：電総研荤報， $\mathbf{5 3}, \mathrm{No} .3,215$ (平元)

(17) 山口, 他：電学論 B, 108, 443 (昭 63-10)

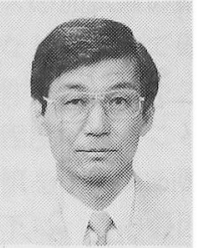

佐 藤康 宏 (正員)

昭和 44 年 3 月早稲田大学電気工学科 卒業。同年 4 月富士電機製造(株) 入社。 同社を経て, 46 年 4 月電子技術総合研 究所入所。同所プラズマ研究室におい て，ピンチ型核融合プラズマ試験装置の建設と実験，およ び核融合装置技術の研究開発に従事。

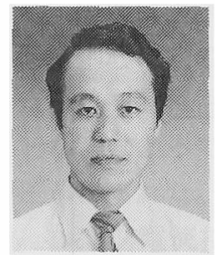

\section{平 野 洋 一 (正員)}

昭和 22 年 8 月 23 日生。 47 年 3 月京 都大学大学院電機工学修士課程修了。同 年 4 月電子技術総合研究所入所。現在, エネルギー基礎部プラズマ研究室にて, 逆磁界ピンチによる核融合の研究に従事。

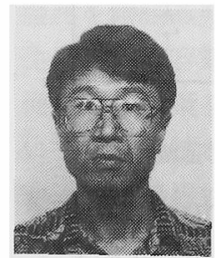

\section{山口作太郎（正員）}

昭和 26 年 11 月生。 55 年 3 月名古屋 大学理学研究科修了。56 年 4 月三菱電 機 (株) 入社後, 核エネルギー開発部に扔 いて，プラズマ核融合装置の設計開発に 従事。平成 4 年 8 月より核融合科学研究所に勤務。 